\title{
ANALYSIS OF EDUCATION SYSTEM FINANCIAL LOSS BASED ON CHOICES OF I YEAR UNIVERISTY STUDENTS COMING FROM VOCATIONAL SECONDARY SCHOOLS IN NORTHERN GREATER POLAND
}

\author{
Jan POLCYN ${ }^{1}$ \\ Maciej GAWRYSIAK ${ }^{2}$
}

\begin{abstract}
Investment in human capital through vocational training may not bring the expected results in accordance with the assumptions of education effectiveness. There are many threats. In previous articles regarding the subject matter discussed in the European Union countries, authors pointed out that in Poland these threats may occur the most. In this article, the authors drew attention to people who, after acquiring vocational qualifications in the vocational education system, started higher education. Using 1644 surveys of first-year higher education students from the years 2012-2017 of the North Greater Poland region, who obtained secondary education while studying in technical schools, the authors estimated the loss of poviat budgets resulting from mismatch of competences acquired in the secondary school to the field of study. A mismatch resulting from a change in the field of education at the level of $60 \%$ in the whole analyzed group was found, which means financial losses of millions of euros.
\end{abstract}

Keywords: economy, education, returns

JEL: I25, I26, I28

\section{Introduction}

In principle, vocational education should enable people who have acquired professional qualifications to enter the labor market immediately after graduating. If this happens, we can call it: success but on the path we can find many obstacles, which may in result lower the expected education effectiveness. Therefore, the quality of human capital, the financial means invested by government in the education system can be forever lost. The measure of the loss lets us somehow help in determination of the distance to expected results and may in effect help in decision making for further solving issues in education system. We can try to avoid the threats and use our resources in more satisfying way in means of total time of vocational education spent on studies by students as well as overall costs of its sustain. The previous research of authors (Polcyn and Gawrysiak 2017) pointed out that the Polish vocational education system is one of the worst performing in the European Union. On the positive side we can say that by identifying and solving these problems we can learn to help vocational education systems also in other countries. The problems found there can be described as the highest unemployment rate of people with vocational education comparing to other EU countries. There is one of the most complicated vocational system combining ordinary secondary school system with extra year of studies (4 overall in comparison to normal 3 years of education as for 2017 year) with post-secondary non-tertiary schools that, although they are in the education system and can

\footnotetext{
${ }^{1}$ Stanisław Staszic University of Applied Sciences in Piła, Podchorążych 10, 64-920 Piła, Poland; phone: +48666346901 email: jpolcyn@pwsz.pila.pl

${ }^{2}$ Stanisław Staszic University of Applied Sciences in Piła, Podchorążych 10, 64-920 Piła, Poland; phone: +48609926797 email: mgawrysiak@pwsz.pila.pl
}

DOI: 10.29302/oeconomica.2018.20.2.2 
receive government dotation, give competences that are of questionable quality. It was also shown that the overall idea of Copenhagen Process (as launched by Copenhagen Declaration, approved on 30 November 2002) did not result in unification of educational vocational systems in European Union even as for 2018. The emphasis on the vocational training in Poland is still big, taking in account that almost $50 \%$ of students enrolling in first year of secondary school would start vocational education. Further development of research (Polcyn and Gawrysiak 2018) let authors show that situation may result from the mismatch of vocational education to the needs of the labor market. The developed methodology and graphical analysis showed how difficult it can be to determine the one and clear answer taking in account how big differences can be between educational subfields of ISCED-F 2013 classes (International Standard Classification of Education introduced by the UNESCO Institute of Statistics for the European Commission, classifies educational programmes and related qualifications by fields and narrow fields of study). At the same time authors showed that there is a big mismatch between the demands of labor market and ongoing education on the poviat level (NTS-4) in whole Poland. Used linear models and logistic regression showed astonishing results that is: no positive impact of the size of government funds per student on the relation between the education subfield-labor market needs. The only positive relation was impact of the foreign capital showing the possibility that the actual needs of labor market created by foreign capital and subfields of vocational education go along much better. Still the threat of possible polarization of the education is present.

Following the train of thought, in the search for the possible answers, authors tried to drew attention to people who, after acquiring vocational qualifications in the vocational education system, started higher education. In this scenario, it is possible to further determine mismatch between not only level of preparation for the labor market demands but also the flexibility of the system and its effectiveness in terms of further education. Authors decided to use 1644 surveys of first-year higher education students from the years 2012-2017 of the Northern Greater Poland region, who obtained secondary education while studying in technical schools. The data further was used by the authors to estimate the loss of poviat budgets resulting from mismatch of competences acquired in the secondary school to the field of study, i.e. lack of continuation of education started at the secondary level. In Poland, vocational training at the secondary level is associated with higher costs than general education, therefore such mismatch generates a loss and means not only wasted money of poviat budgets, but also wasted time by students (additional year of education).

In the article from the literature review, authors showed the different effects of vocational education on GDP and growth, its connection with higher education in terms of competences and continuation of education. Further the complexity of I year students' choices on the field of and its importance in regard to higher education and labor market effectiveness. In the research design authors showed the relation between ISCED-F 2013 subfields of education, the secondary schools profiles and the fields of studies at the universities. Afterwards the way of determination the financial loss and an attempt to include in to estimation loss of an extra year resulting from 4 years of vocational education system. Further in the results the authors showed that the obtained results indicate that the scale of the problem is large. A mismatch resulting from a change in the field of education at the level of $60 \%$ in the whole analyzed group was found, which means financial losses of the budget estimated in financial terms of millions of euros. The authors undertake a discussion on the causes of such a situation and possible solutions which refers to known educational vocational systems from European Union. Afterwards the conclusions from research is being presented and further development and deepening of the studies is proposed.

\section{Literature review}

As a starting point it may be easier to shed some light on the general problem of vocational education basing on its comparison to the general education. As some authors show (Krueger and Kumar, 2004) the differences between them can lead to substantial difference even in economic growth, taking in this case US and Europe as an example. But it is not in favor of vocational education. 
They showed that economy in which policies favor vocational education would grow slower than ones that favor general education. What seems to be even more important, the created gap will grow considerably larger if the rate of available technology grows as well. This seems to be counterintuitive conclusion but it took place in the United States in 1990s. Currently in Poland the situation where about half of the secondary schools students are in vocational education, definitely seems to be problematic. The lack of flexibility in learning in that matter may show itself in the reception of the vocational education graduates in the labor market. While it may not be obvious, the research regarding Asian countries shows different specifics. Researchers (Siddiqui and Rehman, 2017) show that even between East Asian and South Asian countries there might be big differences which may show different influence on GDP depending on the development level of region. Moreover the effect on the GDP may differ from the effect on the growth rate. In that case the significance of secondary education may be visible in countries that have with large population of primary and secondary school graduates and are in transition to tertiary education. What may be more interesting here is that vocational education showed up in this research as a clear determinant of growth regressions in analyzed countries. While this shows the complexity of a problem, authors clearly point out the importance of skills training outside the traditional schooling system while still showing the governmental investments in education may bring out positive results. Still, observing the situation in Germany, Austria, France, we see that the process of "academisation" (that is focusing on tertiary education) which does not necessary mean no vocational education (Hippach-Schneider et al., 2017). In fact various academic programmes start to combine academic with vocational learning (which is also true in many universities in Poland) even though this may not exactly be visible from the outside.

The effect of expectations to competences mismatch is expected to be smaller in vocational education. The researchers show that it may be true but only in the beginning of the career (Verhaest et al., 2018). This effect fades gradually over time though. The mismatch is a general founding in all skills and for more detailed types of skills. The only positive shown is that vocational programmes combine "a specific focus with workplace learning". Another researchers (Baranowska et al., 2011) showed that in the Polish conditions the professional certificate obtained from secondary school does not necessary verify the competences of employee. They showed that "neither firm-based vocational training nor diplomas from more selective tertiary education institutions" would give better chances to keep entry positions in a workplace. The place of diploma was replaced with fixed-term contracts that let employers identify the best workers, which shows devaluation of education.

Students being presented with such situation may in turn try to continue their education on higher level during tertiary education. This may come from being aware that the skills they obtained in secondary schools may be not satisfying for them and for the employers. The importance of decision on the choice of field studies (even if it is choice between academic or vocational) is not simple. Solutions presented by several authors (Fonteyne et al., 2017) show that there are many obstacles in a smooth transition between secondary and higher education. While many possible solutions are available, they include a process of self-exploration as well as psychometric measures which demand a special programm which gives back to student a personal, structured feedback on personal motives and concrete study advice. The need of such systems show that the problem exists, may be solved and the results shown in literature show examples of its big effectiveness. At this moment such systems are very rare and it seems right to say that in Poland there is actually no efficient programme helping students in transition from secondary to higher education. It is more common that student who have already chosen their field of study may look find help in finding a job in university career offices, which are responsible for monitoring careers of students after graduation.

Even in Germany which is often described as an example in proper and early tracking which includes possibility to revise students decisions at later stages problems exist (Biewen and Tapalaga, 2017). Researchers show that even though there is option of "second chance" (decision revision) students with poor background would still rather not take this opportunity. It seems that they are in a way bound to their parental background and would rather preserve the status achieved by their parents. It leads to another conclusion that it is not that important what the parental occupation is but rather 
what the level of education parents represent. This is also the case for the choice between general university and the univeristy of applied sciences and makes economic of financial mechanisms less influential on their choices.

Taking in account importance of facts presented above, authors decided to try to estimate the financial loss of education system originating from the mismatch between field of study choices in secondary and tertiary education level in Poland.

\section{Research design and methodology}

The student database

The base of the research comes from the results of surveys of students that enrolled in I year of university studies in the Northern Greater Poland. From the total number of student authors chose only the ones that came from the actual vocational school and not from the general secondary education. The data collected had to firstly get cleaned from the typo errors and corrected the proper vocational school names as the authors had no access to the original government database of secondary school certificate (Polish "matura") or professional technical school certificate database. Further, depending on the year of graduation authors had to determine the exact profile (ISCED-F 2013- subfields) of studies basing on the information accessible in the governments lists (which made extra problem depending on the year of graduation and the actual programme of the education). Since some of the students only tried to include the schools profile it could be hard to clearly distinguish between the exact profession/competences. Having this situation authors decided to generalize the data. In this case the effect of the loss of information during the generalization could only work in a positive way for educational system. If the results showed bad match between subfield of education and general field of studies they could only be worse if we had the actual detailed data. As it is shown further in the results section, the wasted financial means are high enough even with generalized data and would be higher should authors used more detailed data.

The generalization from the side of the university studies on the I year was as follows. Authors decided that they would not distinguish if student enrolled into one of the specific polytechnic field (like: transport, logistics, electrotechnics, mechanics and so on). In that way any student that graduated from secondary school with technical background, such as profiled school or "technikum": IT school, mechanics school but even also construction school would be counted as correct fit as long as it continued education in one of the polytechnic fields (for example even if student finished secondary school with professional certificate in construction and afterwards "suddenly" continued studies in electrotechnics it would still be counted as a good match). The most clear was the match between economical vocational schools, since it was possible to directly match it with economical field of studies. Because there is a big variation in other professions taught in secondary schools but the number of them was small authors decided to group them all in a so called "various" group. Even with classification including just 3 groups of vocational secondary schools graduates compared to 7 fields of studies, which were: polytechnic (mentioned earlier), economy, philology, physiotherapy, nursery, political science, social work, emergency medical Services the resulting situation was clear enough.

\section{Government funding per student}

To determine the financial loss of educational system first of all it is needed to estimate the costs of education. The government in Poland each year determines the subsidy in the formal document a - so called educational subsidy metric (Polish: Metryczka subwencji oświatowej) - to each poviat in the country. The document has its origins in the division of the educational part of the general subsidy (Regulation of the Minister of National Education of December 15, 2017 on the manner of dividing the educational part of the general subsidy for local government units in 2018). The values are calculated basing on the algorithm described in an attachment to the regulation: Algorithm for dividing the educational part of the general subsidy for local government units in 2018). The actual subsidy metric contains subsidy for a chosen poviat divided in different groups depending on, among other things, the level of education as well as type of education (vocational, general) and the individual needs of students (e.g. disability). While it may not be simple to receive such information, still the Poviats Office (Polish: Starostwo Powiatowe) is obliged to share such information if there is a legitimate reason which was the case. Obtained information that was used, referred to the most actual values concerning educational subsidy of Pila Poviat for the year 2018. Information that authors focused on in the research were as follows:

Sa - (pol. Ucz. Stat. Szk. Publ./niepubl.) - is the base of the subsidy per student. Authors used it as a base according to ways of calculation as defined in algorithm mentioned before i.e. : the number 
of public and non-public school pupils for children and youth and people attending to colleges of social services (not higher education) who provide daytime education, as well as children and youth with intellectual disabilities to a deep degree fulfilling their schooling obligation or education by participating in revalidation and educational activities organized in schools (on the basis of predication about the need for revalidation and upbringing classes) - requiring the use of a special organization of learning and working methods, in the selected local government unit, excluding pupils fulfilling schooling or learning outside of school in accordance with art. 37 paragraph 1 of the Act of 14 December 2016 - Educational Law.

P9 - (pol. Ucz. Szkót ponadgimnazjalnych) - as component of subsidy per student of secondary school, excluding students in general education

P10 - (pol. Ucz. LO) - as component of subsidy per student of secondary schools in general education

\section{Calculations}

To calculate the number of students with "wasted" education, authors decided to firstly obtain the total number of students who got secondary technical education and chose the field of study convergent with this education. As shown in results the size of the group was 614. Therefore knowing that the entire set was made of 1644 students we get a number of 1030 students who, despite their qualifications, have decided to continue their education in a field not related to their education.

In the next step we calculated the financial size of the loss. For the difference between costs of general education and vocational education for 1030 students $C_{d}$ we calculated it as

$$
\mathrm{C}_{\mathrm{d}}=(\mathrm{P} 9-\mathrm{P} 10) * \mathrm{~N}
$$

Using the educational subsidy metric for the Piła poviat for the year 2018, authors used: the cost of education per student ( $\mathrm{Sa}$ - item 1 in metric) in the amount of $€ 1106.56$ (PLN 4 747.13) ${ }^{3}$, the cost of the secondary education excluding general education component per student (P9 - item 21 in metric) in the amount of $€ 1120.75$ (PLN 4 808) and the cost of the secondary general education (P10 - item 22 in metric) $€ 410.02$ (PLN 1 759). Therefore, it was possible to estimate the cost of education of the student and the educational system financial loss according to the following relationship. The cost of education in a technical school per pupil as $\mathrm{Sa}+\mathrm{P} 9$. The cost of education of a general education in secondary school per pupil as $\mathrm{Sa}+\mathrm{P} 10$. The difference in the costs of this education was counted as P9 - P10 and this value was accepted as a unitary "loss" resulting from the incorrect adjustment of the educated profession to the field of study chosen by I year student who might just as well graduate general school. Therefore graduating vocational school was a loss to the educational system as well as the student himself (1 extra year in secondary school).

The value obtained is circa $€ 710.72$ (PLN 3 049.00). It was then multiplied by the number of students with "wasted" education, which finally gives us an expression of $1030 \mathrm{x} € 710.72$ and gives us the value of $€ 732044.29$ (PLN 3140 470). If we calculate the total cost of vocational education of all students in the study, i.e. $1644 \mathrm{x} € 2227.3$ (Sa+P9), we will get the value of $€ 3661685$ for one year. Therefore, the estimated "loss" is nearly $20 \%$ of the total value of the subsidy for students included in the study. Should we take in account 3 years of studies in secondary general education the total loss is around $€ 2196132$.

Even though this is quite a big number, still it is not showing the full scale of ,wasted" financial resources. It also should be taken in account that students from technical secondary schools spend one extra year in the secondary education system. We denote this loss as $\mathrm{C}_{\mathrm{y}}$.

If so, the total number of students with "incorrect" educational track can be multiplied by $\mathrm{Sa}+\mathrm{P} 9$, which we can use to estimate the costs of an extra year. The equation is as follows:

$$
\mathrm{C}_{\mathrm{y}}=(\mathrm{Sa}+\mathrm{P} 9)^{*} \mathrm{~N}
$$

The result alone (rounded value) is $€ 2294122$.

\footnotetext{
${ }^{3}$ Calculated as: 1 euro $=4,29$ polish zloty
} 
The final estimation of the loss is $\mathrm{C}_{\mathrm{t}}$ :

$$
\mathrm{C}_{\mathrm{t}}=\mathrm{C}_{\mathrm{d}}+\mathrm{C}_{\mathrm{y}}
$$

Which gives the result of $€ \mathbf{4} 490$ 254, which of course still does not include value of the one extra year that student spent in vocational school for the student himself.

\section{Results}

From the collected data authors were able to propose detailed data aggregation showed in following graphs and tables which include structures of students interest and their choices depending on the 3 classes of education achieved from secondary vocational education as defined in methodology and 9 fields of study at the university. Presented figures and tables refer to each year of recruitment (2012-2017).

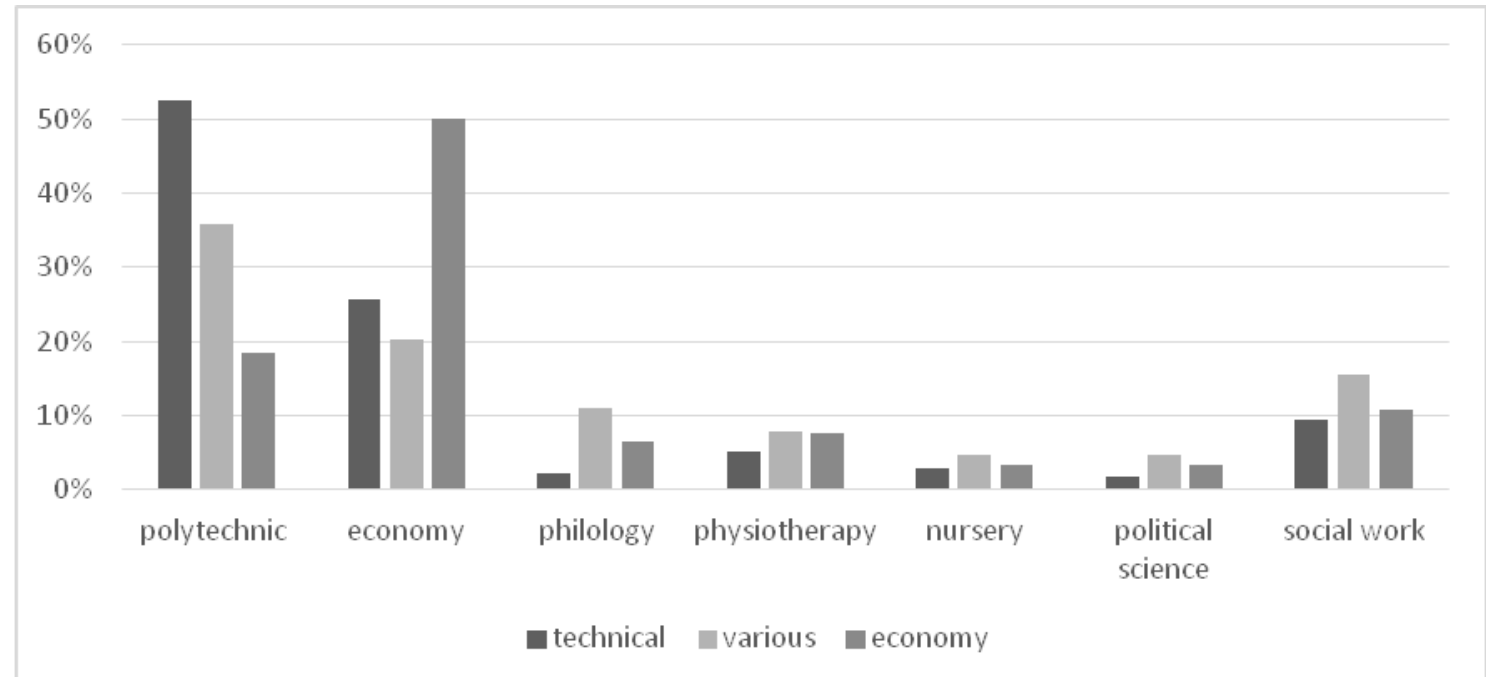

Figure no. 1 The percentage structure of the choice of the field of study depending on the completed secondary vocational school - university recruitment in 2012

Source: own study

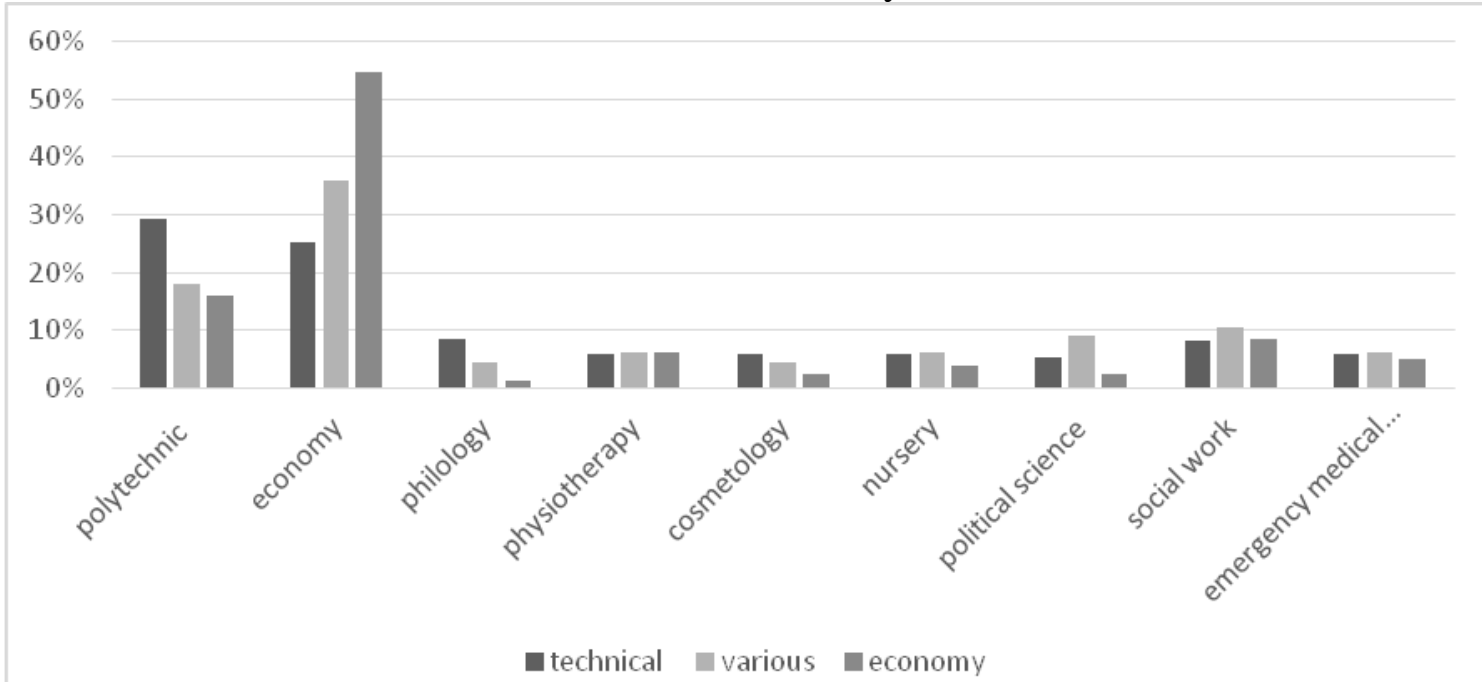

Figure no. 2 The percentage structure of the choice of the field of study depending on the completed secondary vocational school - university recruitment in 2013

Source: own study 


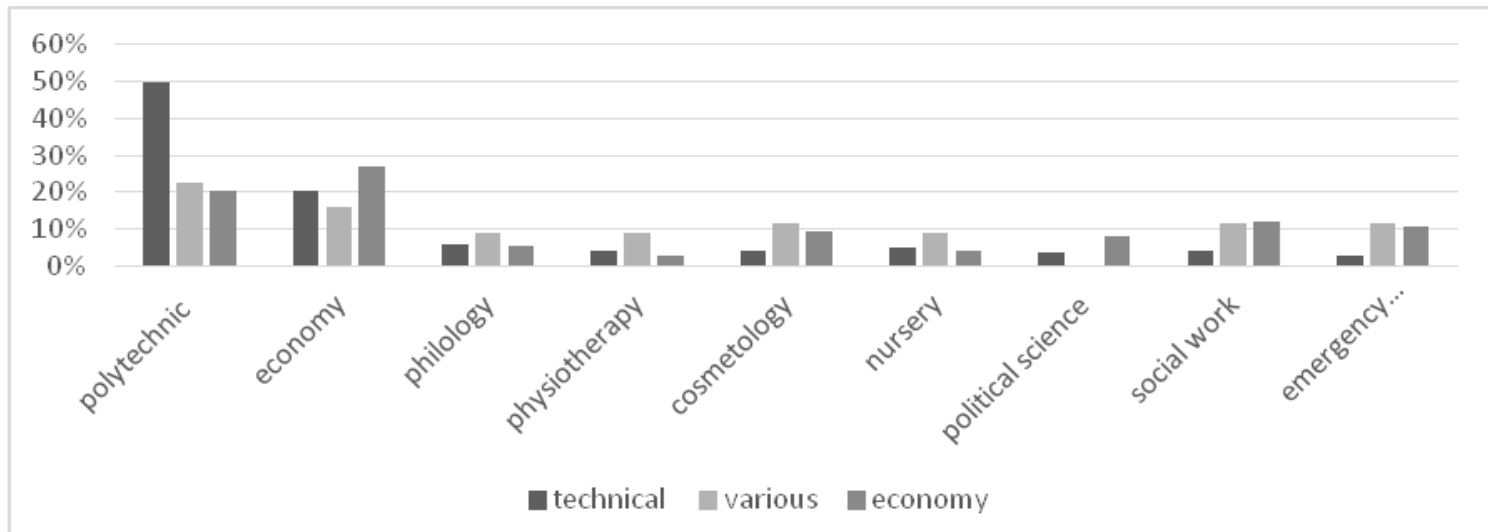

Figure no. 3 The percentage structure of the choice of the field of study depending on the completed secondary vocational school - university recruitment in 2014

Source: own study

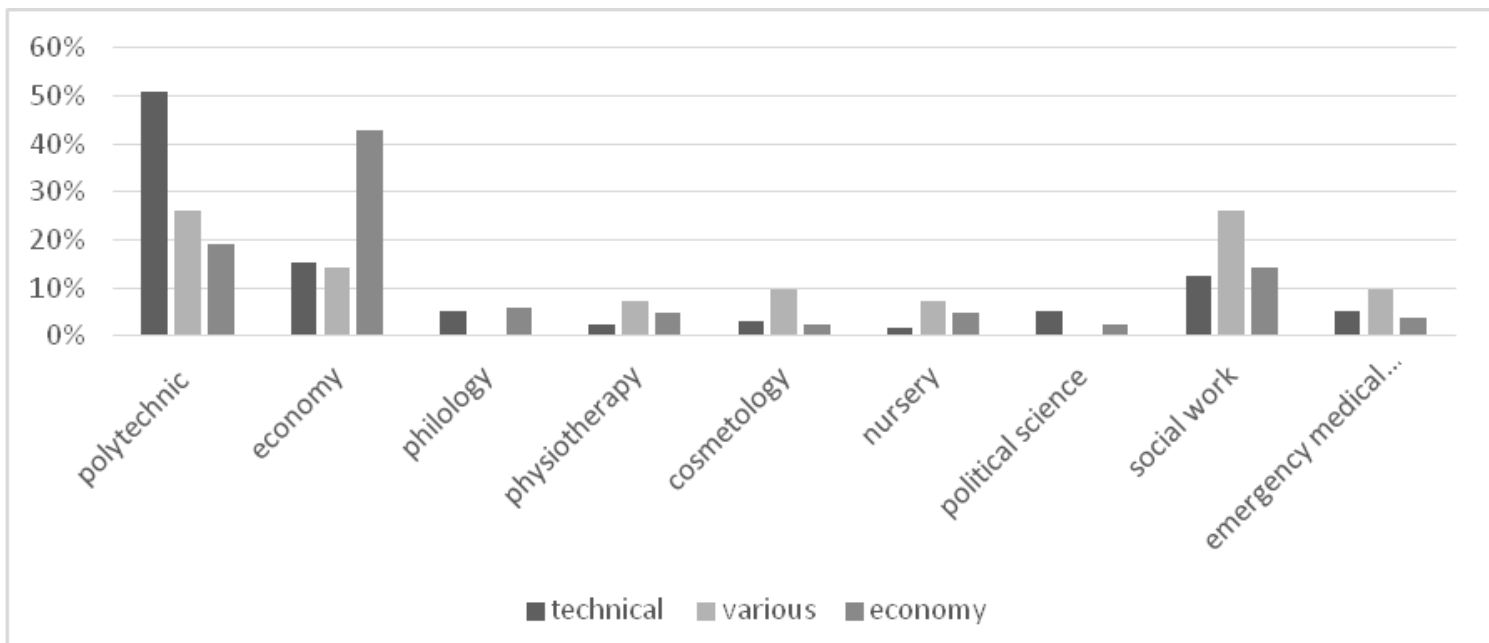

Figure no. 4 The percentage structure of the choice of the field of study depending on the completed secondary vocational school - university recruitment in 2015

Source: own study

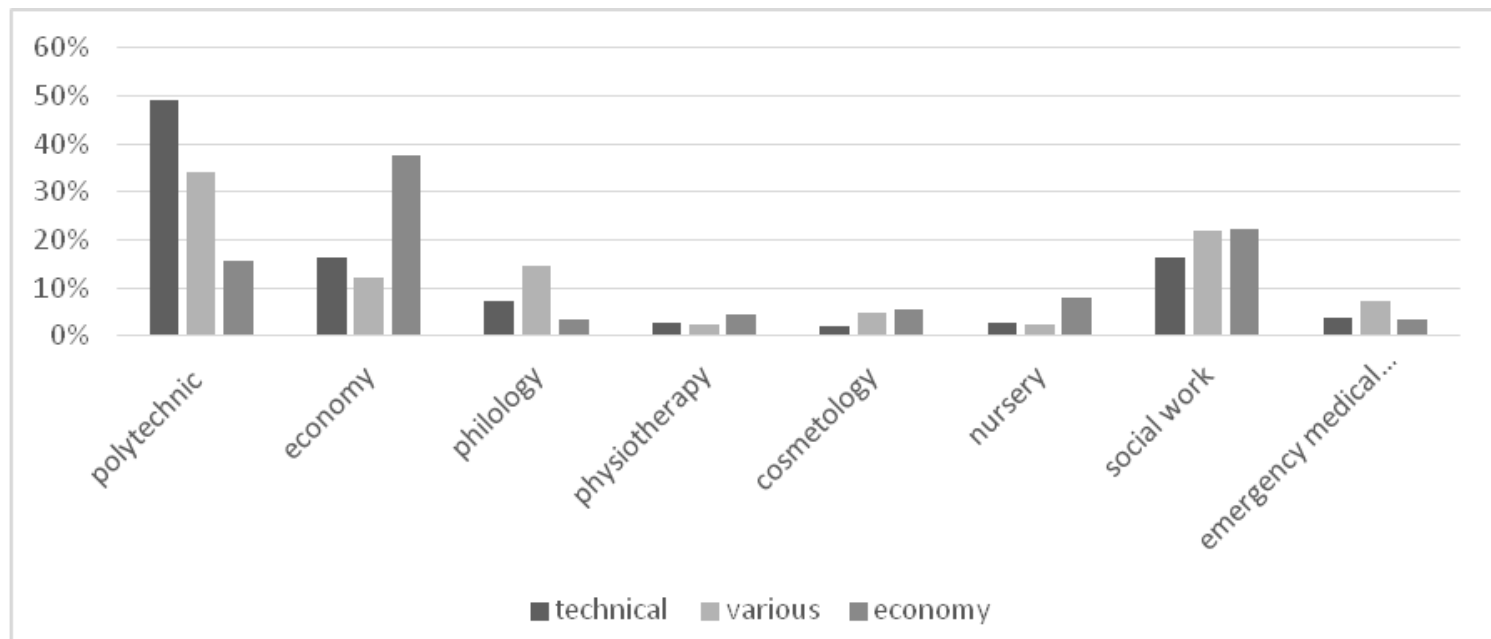

Figure no. 5 The percentage structure of the choice of the field of study depending on the completed secondary vocational school - university recruitment in 2016

Source: own study 


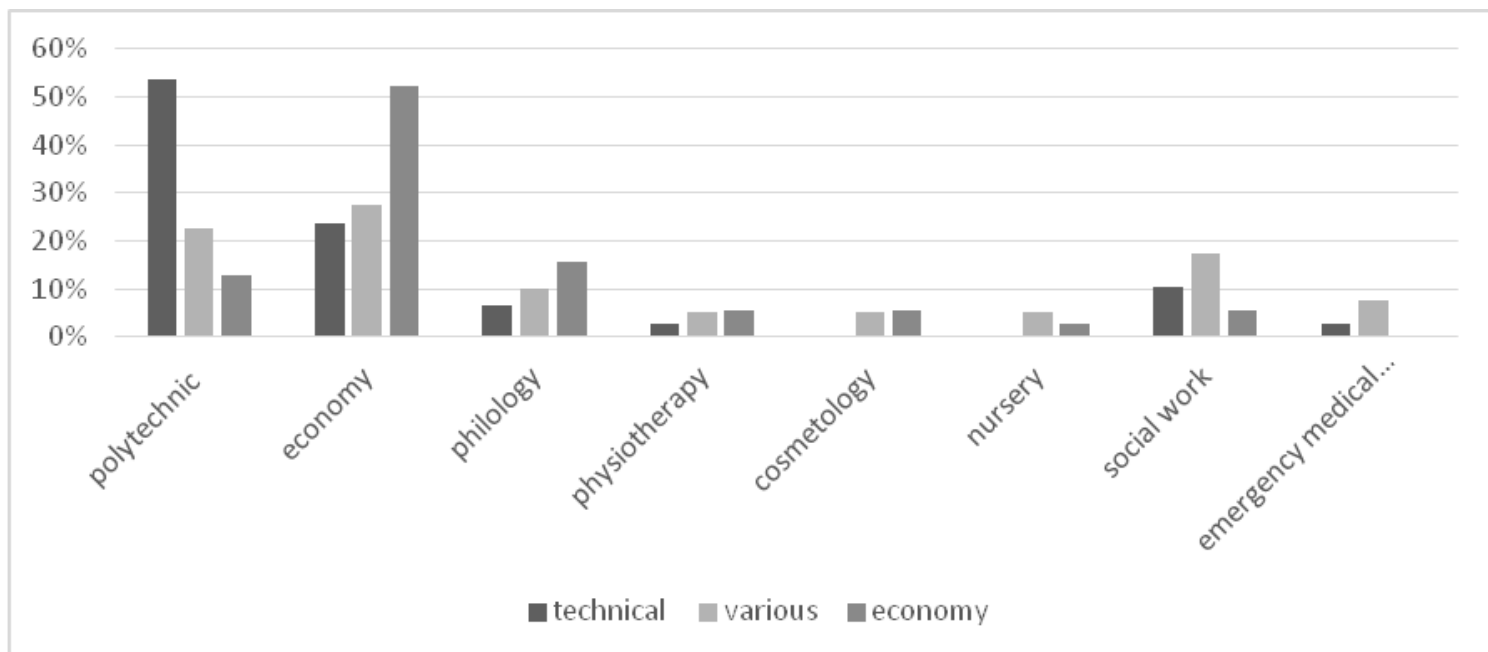

Figure no. 6 The percentage structure of the choice of the field of study depending on the completed secondary vocational school - university recruitment in 2017

Source: own study

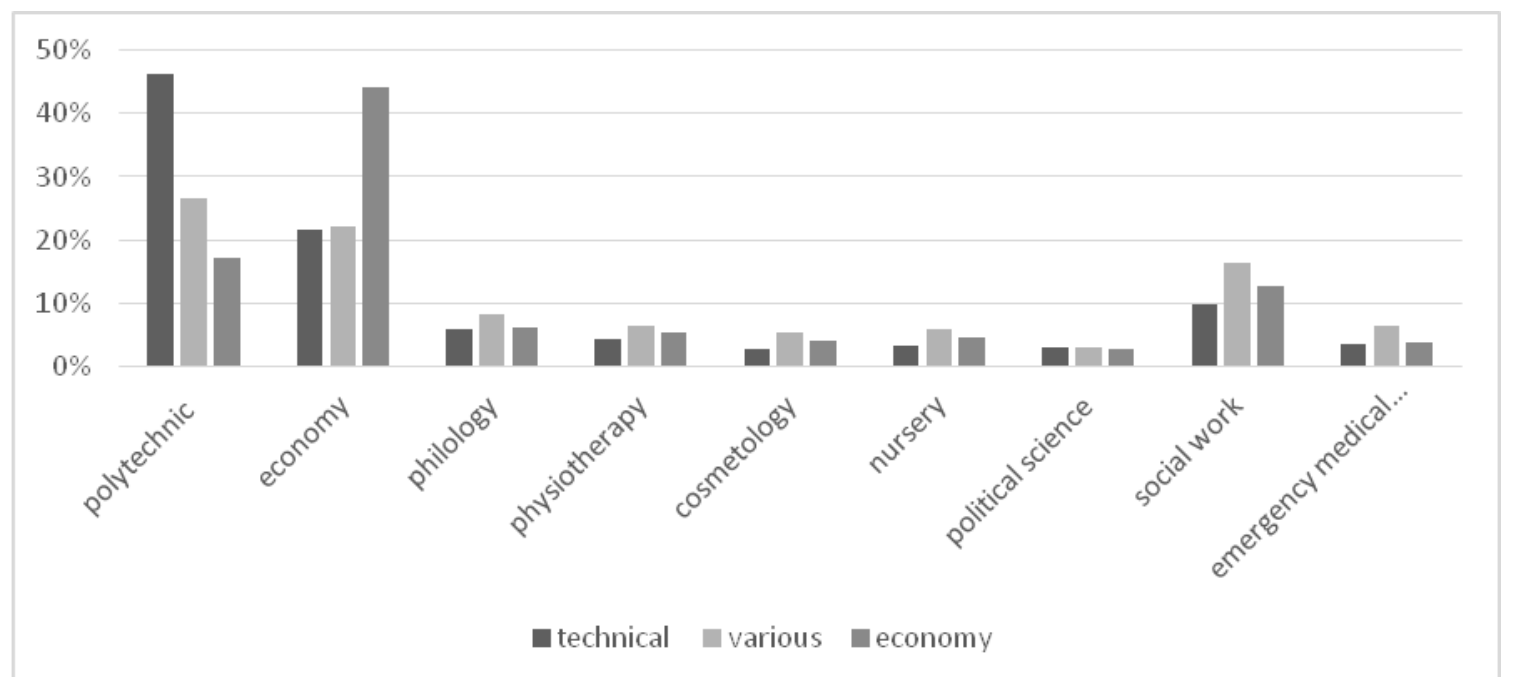

Figure no. 7 The percentage structure of the choice of the field of study depending on the completed secondary vocational school - university recruitment - overall

Source: own study

Below we show the data used for the analysis for each year of the recruitment used in the research (from 2012 - 2017 and overall)

Table 1

Structure of the choice of the field of study depending on the completed secondary vocational school - university recruitment in 2012

\begin{tabular}{|l|c|c|c|}
\hline \multirow{2}{*}{ Field of study } & \multicolumn{3}{|c|}{ Type of vocational education } \\
\cline { 2 - 4 } & technical & various & economy \\
\hline polytechnic & 90 & 23 & 17 \\
\hline economy & 44 & 13 & 46 \\
\hline philology & 4 & 7 & 6 \\
\hline physiotherapy & 9 & 5 & 7 \\
\hline nursery & 5 & 3 & 3 \\
\hline political science & 3 & 3 & 3 \\
\hline
\end{tabular}




\begin{tabular}{|c|c|c|c|} 
social work & 16 & 10 & 10 \\
\hline
\end{tabular}

Table 2

Structure of the choice of the field of study depending on the completed secondary vocational school - university recruitment in 2013

\begin{tabular}{|l|c|c|c|}
\hline \multirow{2}{*}{ Field of study } & \multicolumn{3}{|c|}{ Type of vocational education } \\
\cline { 2 - 4 } & technical & various & economy \\
\hline polytechnic & 55 & 12 & 13 \\
\hline economy & 47 & 24 & 45 \\
\hline philology & 16 & 3 & 1 \\
\hline physiotherapy & 11 & 4 & 5 \\
\hline cosmetology & 11 & 3 & 2 \\
\hline nursery & 11 & 4 & 3 \\
\hline political science & 10 & 6 & 2 \\
\hline social work & 15 & 7 & 7 \\
\hline emergency medical services & 11 & 4 & 4 \\
\hline
\end{tabular}

Source: own study

Table 3

Structure of the choice of the field of study depending on the completed secondary vocational school - university recruitment in 2014

\begin{tabular}{|l|c|c|c|}
\hline \multirow{2}{*}{ Field of study } & \multicolumn{3}{c|}{ Type of vocational education } \\
\cline { 2 - 4 } & technical & various & economy \\
\hline polytechnic & 70 & 10 & 15 \\
\hline economy & 29 & 7 & 20 \\
\hline philology & 8 & 4 & 4 \\
\hline physiotherapy & 6 & 4 & 2 \\
\hline cosmetology & 6 & 5 & 7 \\
\hline nursery & 7 & 4 & 3 \\
\hline political science & 5 & - & 6 \\
\hline social work & 6 & 5 & 9 \\
\hline emergency medical services & 4 & 5 & 8 \\
\hline
\end{tabular}

Source: own study

Table 4

Structure of the choice of the field of study depending on the completed secondary vocational school - university recruitment in 2015

\begin{tabular}{|l|c|c|c|}
\hline \multirow{2}{*}{ Field of study } & \multicolumn{3}{c|}{ Type of vocational education } \\
\cline { 2 - 4 } & technical & various & economy \\
\hline polytechnic & 70 & 11 & 16 \\
\hline economy & 21 & 6 & 36 \\
\hline philology & 7 & - & 5 \\
\hline physiotherapy & 3 & 3 & 4 \\
\hline cosmetology & 4 & 4 & 2 \\
\hline nursery & 2 & 3 & 4 \\
\hline political science & 7 & - & 2 \\
\hline
\end{tabular}




\begin{tabular}{|l|c|c|c|}
\hline social work & 17 & 11 & 12 \\
\hline emergency medical services & 7 & 4 & 3 \\
\hline
\end{tabular}

Source: own study

Table 5

Structure of the choice of the field of study depending on the completed secondary vocational school - university recruitment in 2016

\begin{tabular}{|l|c|c|c|}
\hline \multirow{2}{*}{ Field of study } & \multicolumn{3}{c|}{ Type of vocational education } \\
\cline { 2 - 4 } & technical & various & economy \\
\hline polytechnic & 54 & 14 & 14 \\
\hline economy & 18 & 5 & 34 \\
\hline philology & 8 & 6 & 3 \\
\hline physiotherapy & 3 & 1 & 4 \\
\hline cosmetology & 2 & 2 & 5 \\
\hline nursery & 3 & 1 & 7 \\
\hline social work & 18 & 9 & 20 \\
\hline emergency medical services & 4 & 3 & 3 \\
\hline
\end{tabular}

Source: own study

Table 6

Structure of the choice of the field of study depending on the completed secondary vocational school - university recruitment in 2017

\begin{tabular}{|l|c|c|c|}
\hline \multirow{2}{*}{\multicolumn{1}{|c}{ Field of study }} & \multicolumn{3}{|c|}{ Type of vocational education } \\
\cline { 2 - 4 } & technical & various & economy \\
\hline polytechnic & 57 & 9 & 9 \\
\hline economy & 25 & 11 & 37 \\
\hline philology & 7 & 4 & 11 \\
\hline physiotherapy & 3 & 2 & 4 \\
\hline cosmetology & - & 2 & 4 \\
\hline nursery & - & 2 & 2 \\
\hline social work & 11 & 7 & 4 \\
\hline emergency medical services & 3 & 3 & - \\
\hline
\end{tabular}

Source: own study

Table 7

Structure of the choice of the field of study depending on the completed secondary vocational school - university recruitment - overall

\begin{tabular}{|l|r|r|r|}
\hline \multirow{2}{*}{ Field of study } & \multicolumn{3}{|c|}{ Type of vocational education } \\
\cline { 2 - 4 } & technical & various & economy \\
\hline polytechnic & 396 & 79 & 84 \\
\hline economy & 184 & 66 & 218 \\
\hline philology & 50 & 24 & 30 \\
\hline physiotherapy & 35 & 19 & 26 \\
\hline cosmetology & 23 & 16 & 20 \\
\hline nursery & 28 & 17 & 22 \\
\hline political science & 25 & 9 & 13 \\
\hline social work & 83 & 49 & 62 \\
\hline
\end{tabular}




\begin{tabular}{|l|r|r|r|}
\hline emergency medical services & 29 & 19 & 18 \\
\hline \multicolumn{3}{|c|}{ Source: own study }
\end{tabular}

\section{Discussion}

The results presented above show the distribution of choices in numbers and percentages. The figures show the proportions of students coming from selected type of secondary education divided among each field of study at the university. The tables show the structure of field of study regarding the secondary level type of vocational education of I year students. We can see only around $46 \%$ of secondary level graduates with background in technical ISCED-F 2013 subfield of education choosing as a continuation polytechnical field of study at the university. For the economical subfield the match on the tertiary level of education was estimated as $44 \%$. For the „various” group match could only be calculated regarding the choice of economical or polytechnic field of study on the I year therefore the mismatch level is 49\%. The overall number of 1030 individuals with mismatch even for this research group could be bigger, should more detailed tracking information had been provided. The overall mismatch is estimated on $62 \%$. The studies showing mismatch between labor market expectations and vocational education graduates estimated on 50\% and higher are unfortunately common (Béduwé and Giret, 2011) but still it may differ among the diverse subfield of secondary education and occur much better for technical subfield graduates (Polcyn and Gawrysiak, 2018). Unfortunately in case when it is only up to student to choose the field of study and this decision does not take in account third parties, having the same level of mismatch or higher seems to be a very big problem. In Poland students can enroll in practically any field of study on higher level of education, regardless the previous education direction. Some studies show that the choices can depend on the socio-economical level and parental situation (Tieben et al., 2010). There is not much research on that matter but some other studies show that in other countries problem seems to be smaller (exemplary proportion: while $14 \%$ of graduates of vocational education on secondary level in Finland would continue on polytechnic only $1 \%$ on university (Kilpi-Jakonen, 2011)).

\section{Conclusion}

The aim of the research was to estimate the financial loss of Polish educational system basing on the choices of 1644 I year university students coming from vocational secondary schools in North Greater Poland. While the result is significantly showing the overall mismatch of over $60 \%$ of students, the financial loss was estimated close to 4.5 million euro. The results of these research may be the "hard effect" of problems in vocational education presented in previous publications of authors on this matter (Polcyn \& Gawrysiak, 2017, 2018).

For the purpose of this article the goals were achieved but further research is necessary. The analysis of the differences in gender as well as a more general research in bigger region ought to be taken into account. This may show if the size of the problem (proportions) is connected with the spatial distribution. While further and detailed analysis is needed, the possible sources of shown problems lead to flaws of current vocational educational system in Poland. Its complexity (many paths, postsecondary non tertiary level of vocational education), mismatch to labor market demands and inertia.

\section{References}

1. Baranowska, A., Gebel, M., Kotowska, I.E., 2011. The role of fixed-term contracts at labour market entry in Poland: stepping stones, screening devices, traps or search subsidies? Work Employ. Soc. 25, 777-793. https://doi.org/10.1177/0950017011419705

2. Béduwé, C., Giret, J.-F., 2011. Mismatch of vocational graduates: What penalty on French labour market? Journal of Vocational Behavior 78, 68-79. https://doi.org/10.1016/j.jvb.2010.09.003

3. Biewen, M., Tapalaga, M., 2017. Life-cycle educational choices in a system with early tracking and "second chance" options. Econ. Educ. Rev. 56, 80-94. https://doi.org/10.1016/j.econedurev.2016.11.008 
4. Fonteyne, L., Wille, B., Duyck, W., De Fruyt, F., 2017. Exploring vocational and academic fields of study: development and validation of the Flemish SIMON Interest Inventory (SIMON-I). Int. J. Educ. Vocat. Guid. 17, 233-262. https://doi.org/10.1007/s10775-016-9327-9

5. Hippach-Schneider, U., Schneider, V., Menard, B., Tritscher-Archan, S., 2017. The underestimated relevance and value of vocational education in tertiary education - making the invisible visible. J. Vocat. Educ. $\quad$ Train. https://doi.org/10.1080/13636820.2017.1281342

6. Kilpi-Jakonen, E., 2011. Continuation to upper secondary education in Finland: Children of immigrants and the majority compared. Acta Sociol. 54, 77-106. https://doi.org/10.1177/0001699310392604

7. Krueger, D., Kumar, K.B., 2004. Skill-specific rather than general education: A reason for USEurope growth differences? J. Econ. Growth 9, 167-207. https://doi.org/10.1023/B:JOEG.0000031426.09886.bd

8. Polcyn, J., Gawrysiak, M. 2018. Analysis of the effectiveness of vocational education in terms of labor market demand in Poland, Web Of Science - Web of Conferences, Conference Proceeedings

9. Polcyn, J., Gawrysiak, M., 2017. Europejski system kształcenia zawodowego - dyskusja nad możliwością poprawy efektywności. Zeszyty Naukowe Wydziału Nauk Ekonomicznych Politechniki Koszalińskiej 21, 179-197.

10. Rozporządzenie Ministra Edukacji Narodowej z dnia 15 grudnia 2017 r. w sprawie sposobu podziału części oświatowej subwencji ogólnej dla jednostek samorządu terytorialnego $\mathrm{W}$ roku 2018 [WWW Document], n.d. URL http://prawo.sejm.gov.pl/isap.nsf/DocDetails.xsp?id=WDU20170002395 (accessed 10.16.18).

11. Siddiqui, A., Rehman, A.U., 2017. The human capital and economic growth nexus: in East and South Asia. Appl. Econ. 49, 2697-2710. https://doi.org/10.1080/00036846.2016.1245841

12. Tieben, N., Wolbers, M.H.J., 2010. Transitions to post-secondary and tertiary education in the Netherlands: a trend analysis of unconditional and conditional socio-economic background effects. High. Educ. 60, 85-100. https://doi.org/10.1007/s10734-009-9289-7

13. Verhaest, D., Lavrijsen, J., Van Trier, W., Nicaise, I., Omey, E., 2018. General education, vocational education and skill mismatches: short-run versus long-run effects. Oxf. Econ. Pap.-New Ser. 70, 974-993. https://doi.org/10.1093/oep/gpv026

14. Załącznik do Rozporządzenia Ministra Edukacji Narodowej z dnia 15 grudnia 2017 r. w sprawie sposobu podziału części oświatowej subwencji ogólnej dla jednostek samorządu terytorialnego w roku 2018: Algorytm Podziału Części Oświatowej Subwencji Ogólnej Dla Jednostek Samorządu Terytorialnego Na Rok 2018 [WWW Document], n.d. URL http://prawo.sejm.gov.pl/isap.nsf/DocDetails.xsp?id=WDU20170002395 (accessed 10.16.18). 